11. Lockhead, G. R. (1992). On identifying things: a case for context. In B. Burns (Ed.), Percepts, Concepts, and Categories. The Representation and Processing of Information (pp. 109-143). Amsterdam: Elsevier Science Publishers [in English].

12. Medin, D., \& Ortony, A. (1989). Psychological essentialism. In S. Vosniadou \& A. Ortony (Eds.), Similarity and Analogical Reasoning (pp. 179-195). Cambridge: Cambridge University Press [in English] 316 [in English].

13. Murphy, G. L., \& Medin, D. L. (1985). The role of theories in conceptual coherence. Psychological Review, 92(3), 289-

14. Smith, L. B., \& Heise, D. (1992). Perceptual similarity and conceptual structure. In B. Burns (Ed.), Percepts, Concepts, and Categories. The Representation and Processing of Information (pp. 233-272). Amsterdam: Elsevier Science Publishers [in English].

15. Tversky, A. (1977). Features of similarity. Psychological Review, 84(4), 327-352 [in English].

Стаття надійшла до редакції 10.05.2019 p.

УДК 78.01:78.07]:001.8

\author{
Довжинець Інна Георгіївна \\ кандидат мистецтвознавства, доцент, \\ доцент кафедри хореографії та \\ музично-інструментального виконавства \\ Сумського державного педагогічного \\ університету ім. А. С. Макаренка \\ ORCID: 0000-0002-9663-2576 \\ inna.dov@gmail.com
}

\title{
МУЗИЧНЕ СЕРЕДОВИЩЕ: ДОСВІД ТЕОРЕТИЧНОГО АНАЛІЗУ
}

\begin{abstract}
Мета роботи - на основі узагальнення сутнісних характеристик «середовища» як універсальної категорії різних галузей наукових знань, надати визначення поняття «музичне середовище». Методологія дослідження базується на застосуванні компаративного, теоретичного, аналітичного методів, а також загальнонаукових підходах зіставлення, систематизації та узагальнення, які дають змогу комплексно вивчити предмет дослідження. Наукова новизна полягає у введенні в науковий обіг нової дефініції. Висновки. Музичне середовище є універсальним поняттям, оскільки охоплює всі компоненти процесу творення звукового музичного простору та його сприйняття. Музичне середовище становить цілісний феномен, основою якого $є$ музична діяльність. Складна багаторівнева структура, організована за принципом взаємозв'язку, взаємозалежності та взаємообумовленості елементів, дозволяє прирахувати музичне середовище до системних явищ. Загалом, під музичним середовищем розуміється звукове оточення індивіда, що формується в процесі музичної діяльності і охоплює всі її складові: творчість, виконавство, розповсюдження та сприйняття. Воно обумовлюється часо-просторовими чинниками та динамікою соціальних змін.

Ключові слова: дослідження, поняття, середовище, загальнонауковий підхід, музична діяльність.
\end{abstract}

Довжинец Инна Георгиевна, кандидат искусствоведения, доцент, доцент кафедры хореографии и музыкальноинструментального исполнительства Сумского государственного педагогического университета им. А. С. Макаренко

Музыкальная среда: опыт теоретического анализа

Цель работы - на основе обобщения сущностных характеристик «среды» как универсальной категории различных отраслей научных знаний, дать определение понятия «музыкальная среда». Методология исследования базируется на применении компаративного, теоретического, аналитического методов, а также общенаучных подходах сопоставления, систематизации и обобщения, которые позволяют комплексно изучить предмет исследования. Научная новизна заключается во введении в научный оборот новой дефиниции. Выводы. Музыкальная среда является универсальным понятием, поскольку охватывает все компоненты процесса создания звукового музыкального пространства и его восприятия. Музыкальная среда представляет целостный феномен, основой которого является музыкальная деятельность. Сложная многоуровневая структура, организованная по принципу взаимосвязи, взаимозависимости и взаимообусловленности элементов, позволяет причислить музыкальную среду к системным явлениям. В целом, под музыкальной средой следует понимать звуковое окружение индивида, которое формируется в процессе музыкальной деятельности и охватывает все ее составляющие: творчество, исполнительство, распространение и восприятие. Она обуславливается временно-пространственными фракторами и динамикой социальных изменений.

Ключевые слова: исследование, понятие, среда, общенаучный подход, музыкальная деятельность.

Dovzhynets Inna, Ph.D. in Arts, associate professor, associate professor of a department of choreography and musicinstrumental performance of A. S. Makarenko Sumy National Pedagogical University

Musical environment: the experience of theoretic analysis

The purpose of the work is to give the definition of a notion «musical environment» using a generalization of essential characteristics of «environment» as a universal category relating to different branches of scientific knowledge. The methodology of the study is based upon the use of comparative, theoretic, analytical methods and also general scientific approaches of comparison, systematization, and generalization which help to make a complex investigation of the object. The scientific novelty consists in introducing a new definition. Conclusion. The musical environment is a universal notion as it includes all components of sound music field creation process and perception of this field. Musical environment is an integral phenomenon basing upon music activity. Complex multi-level structure organized by the principle of interrelation, interdependency, and interconditionality of the elements helps to refer musical environment to the systemic phenomenon. In general, musical environment is a sound surrounding of the individual formed in the process of musical activity and covers all its components: creativity, performing, spreading and perception. It is influenced by time and place factors and by dynamics of social changes.

Key words: investigation, notion, environment, general scientific approach, musical activity.

Актуальність теми дослідження. В науковій і музикознавчій літературі термін «музичне середовище» часто використовується в контексті досліджень музичного життя та різних фрорм його існування (концертної, гастрольної, фрестивальної, конкурсної практики і т. ін.). Проте, до цього часу не існує

() Довжинець І. Г., 2019 
чіткого визначення самого поняття «музичне середовище». Не дослідженими залишаються й питання його фрормування та функціонування, вплив на процеси музичної творчості, діяльність митця.

Мета дослідження полягає у визначенні поняття «музичне середовище».

Виклад основного матеріалу. В сучасному мовному обігу термін «середовище» широко використовується у різноманітних значеннях. Зокрема, під ним розуміють світ, систему, речовину, тіло, умови, фрактори і т. ін. Водночас, в загальному сенсі саме слово відтворює дві основні сутності: предметно-просторове оточення (environment - довкілля) та соціальну сферу людської діяльності (milieu оточення).

Первинне значення терміну пов'язано з екологічним тлумаченням його, як простору, в якому відбувається життєдіяльність живих організмів. За визначенням німецького біолога, засновника терміну «екологія» Е. Геккеля, «оточуюче середовище» означає «в широкому сенсі всі умови існування організмів» $[25,286]$. Поглиблюючи це формулювання, російський фрізіолог І. Сеченов підкреслював, що «організм без зовнішнього середовища, яке підтримує його існування, неможливий» [14, 258] і наголошував, що на організми впливають не загальні умови існування, а «те середовище, в якому вони мешкають» $[15,412]$.

Наближеним до екологічного є трактування географічного (або природного) середовища, яке розуміють як земне оточення людини: сукупність предметів і явищ природи, що включені в сферу діяльності людей і є необхідною умовою існування суспільства $[21,236]$.

Цілком логічно, що соціологія, як наука про суспільство і закономірності його функціонування, також оперує терміном «середовище», який в даному випадку означає сукупність матеріальних, економічних, соціальних, політичних і духовних умов існування, фрормування і діяльності індивідів та соціальних груп [19, 624]. За класифікацією розрізняється: макросередовище - соціально-економічна система в цілому (економіка, суспільні інститути, суспільна свідомість, культура) та мікросередовище безпосереднє соціальне оточення людини (сім'я, робота, навчання та інші групи).

Соціальне середовище має безпосередній вплив на свідомість, поведінку і психіку людини, тому природно, що психологія вивчає психічні процеси і властивості окремих індивідів не самі по собі, а в їх реальній взаємодії із середовищем. Ще давньогрецькі фрілософи вказували на важливість соціального оточення у фрормуванні поведінкових реакцій жителів полісу [10]. Значно пізніше, фрранцузькі просвітителі П.Гольбах і К.Гельвецій детально зайнялися цією проблемою і визначали вирішальну роль середовища у формуванні психічних, моральних та інших характеристик людини [2, 424]. Розробку цієї ідеї продовжив фундатор соціології, французький фрілософр-позитивіст О. Конт. Досліджуючи закони функціонування суспільства, він вивів поняття «середовища» в ранг основоположних і в контексті його розглядав психічні функції індивіда [5]. Погляди О. Конта були розвинуті англійським фрілософом, соціологом і психологом Г. Спенсером. Спираючись на теорію біологічної еволюції, засновник органічної школи в соціології висунув ідею існування організму не самого по собі, а системи «організм-середовище», в якому психіка $€$ механізмом адаптації організму до оточуючого середовища [16].

Ця концепція отримала критику відомого радянського вченого - С. Рубінштейна. Науковець наголошував, що будучи об'єктом впливу з боку середовища, суб'єкт також «сам впливає на середовище, змінює його, регулюючи ті умови, які обумовлюють його діяльність» [12, 81].

Взаємозалежний вплив оточуючого середовища і особистості на початку XX століття став об'єктом активного вивчення іноземних шкіл психології. Зокрема, фундатор «індивідуальної психології» австрієць А. Адлер підкреслював, що люди є «творчими істотами, які не тільки реагують на своє оточення, а й впливають на нього» [23, 133]. Згодом, американський представник біхевіоризму Б. Скіннер, радикально змінивши предмет психології з свідомості на поведінку, заявив, що саме середовище (соціальне, культурне, родинне та інше) є визначальним фактором поведінки людини [11].

Новітні психологічні концепції репрезентують сучасний погляд на взаємини людини та оточуючого середовища. Одним з напрямом вивчення цієї проблематики є психологія середовища (environmental psychology), яка розглядає середовище як результат взаємодії з індивідом, де визначальним $€$ можливість змінювати середовище на потребу створення психологічно комфортних умов для ефективної діяльності особистості. В цьому контексті сучасний естонський дослідник М. Хейдметс акцентує увагу на тому, що середовище не є еквівалентом поняття «світ», оскільки охоплює тільки ту його частину, з якою суб'єкт так чи інакше взаємодіє. “Світ» може існувати без суб'єкта, тоді як «середовище» тільки при його наявності [20, 129].

Значного поширення поняття «середовище» отримало в соціології культури. В контекст цієї науки його ввів фрранцузький фрілософр І. Тен. Послідовник позитивізму, засновник культурно-історичної школи в розробленій ним «теорії моментів», визначив, що факторами, які впливають на мистецтво $є$ раса (особливості національного характеру, менталітету), історія (як певний часовий етап існування культури) та середовище (як географічне, так і соціальне). Середовище «породжує свої результати» писав автор теорії [17, 61]. Щоб зрозуміти будь-який художній твір, митця або школу, необхідно в точності уявити собі середовище, яке їх породило, адже «між твором і середовищем є точна і неодмінна відповідність» $[17,63]$. 
3 позицій історизму поняття культурне середовище в XX столітті розглядав також російський соціолог, один з основоположників концепції євразійства П. Савицький. Розмірковуючи над здобутками культури в різні історичні часи, вчений сформулював три основні компоненти, оперуючи якими «можна наблизитися до найбільш повного пізнання» характеру певної культури. Це: «культурне середовище», «епоха» існування культурного середовища та «галузі» культури [13, 100-106].

Процеси глобалізації в усіх сфрерах життя, що охопили світ наприкінці XX-початку XXI століть, позначились на переосмисленні поняття «екологія» та його атрибуту «середовище» у бік поширення їх сутнісних характеристик на усі сфери життєдіяльності. Терміни отримали міждисциплінарного значення і стали використовуватися різними науками, зокрема, музикознавством.

Поштовхом до вивчення проблем музичної екології стала стаття $Є$. Назайкінського «Музика та екологія», в якій вчений визначив три області де проблеми цих наук збігаються: «музика як шум, забруднення акустичного середовища»; як сфера художніх і естетичних норм та ідеалів, що потребує чистоти і в цьому аспекті пов'язана з екологією; як репрезентант «духовного світу людини, який є полем екологічного впливу» і водночас причиною екологічних змін середовища $[9,18]$.

Ґрунтовного вивчення питання екології музичної культури отримали в монографічному дослідженні литовського піаніста Л. Мельникаса [8]. Окремий розділ науковець присвятив розробці поняття «музично-звукове середовище», розглядаючи його як компонент фоносфери людського буття. Серед фракторів формування такого середовища вчений акцентував увагу на регіональному чиннику, який, на його думку, є визначальним і «обумовлює специфіку творчої діяльності» у певній місцевості $[8,118]$. Безпосередньо музичне середовище, зазвичай, вивчається в контексті проблем музичної педагогіки. Воно розглядається як засіб впливу на дитину - інструмент «залучення її до музичної культури» [1], «музичне оформлення життєдіяльності дітей» [6], або ж один з напрямів, видів виховання, який «формує індивідуальній досвід» малечі [7].

Одним з перших музикознавчих досліджень, присвяченим питанням формування музичного середовища стала написана понад чверть століття тому робота російської авторки І. М Головач [3]. Уточнюючи зміст ключового поняття дослідження, науковець вказує, що структура музичного середовища «може бути представлена через взаємодію двох основних блоків: продуктів музичної творчості та їх споживачів», тому під самим терміном розуміється «сукупність музичних творів (стилів, жанрів, видів, інтонацій), з яким взаємодіє соціальний суб'єкт (особистість, група, клас, суспільство) і які впливають на його потреби, смаки, інтереси, ціннісні орієнтації, а також на його діяльність по створенню, зберіганню, розповсюдженню та споживанню музики у певних історичних умовах» [3, 6-7].

Як об'єкт музичного краєзнавства вивчає музичне середовище сучасна українська дослідниця О. Кавунник. Зокрема, вона наголошує, що цей термін, «пов'язаний із означенням репрезентативної сорери музичної культури міста», включає «сукупність усіх музичних аспектів культури міста (селища, регіону), що формується завдяки діяльності музикантів-професіоналів і аматорів, представників академічної і традиційної музичної культури» [4, 5].

Отже, сучасна наукова думка не дійшла консенсусу щодо визначення поняття «середовище» $\mathrm{i}$ це цілком виправдано, оскільки кожна галузь в трактуванні його сутності передбачає особливість предмету свого дослідження. Зокрема, англійський дослідник середовища Н. Теймур в монографії «Екологічний дискурс» наводить більше сорока фрормулювань поняття «середовище» [24]. Водночас, наявність різнобічних тлумачень виявляє багатомірність і складність поняття в сукупності всіх його компонентів. Для з'ясування дефініції «музичне середовище» спробуємо екстраполювати вищенаведені параметри середовища на специфічно музичний простір.

Музичне, як і кожне середовище, має свою структуру, фрактори формування, умови функціонування, спрямованість, характер впливу тощо. На макрорівні музичне середовище включає всю музично-звукову атмосферу Землі, митців, музичні організації, актуальний музичний продукт і той, що існує в потенційному використанні. 3 поширенням всесвітньої мережі інтернет, можна говорити про те, що макромузичне середовище сьогодні $€$ реально існуючою константою. На мікрорівні - це безпосереднє музичне оточення людини на будь-якому місті її перебування «тут і зараз». Увесь звуковий фон, що за висловом Г. Канчелі «нас оточує сьогодні вже скрізь, куди б ми ні зайшли». Музика, яка звучить «в ліфтах великих універмагів <..>, яка звучить в <..> таксі, музика, яка звучить в концертах, якщо ви йдете ввечері на концерт, музика яка звучить на вулиці...» [18].

Формування музичного середовища відбувається в комплексі двох основних чинників: часового, що визначається певним історичним періодом та просторового - пов'язаного з країною, регіоном, усталеною системою національних цінностей і традицій. В межах цих базових платформ розрізняються інші типи музичного середовища, зокрема, середовище міста (столиці, провінції), окремого концертного або навчального музичного закладу, творчого колективу і т. ін.

Утворюючись в контексті музичної діяльності, музичне середовище включає всі:

- різновиди музичного мистецтва як: академічне фольклорне, естрадне, духовну музику;

- форми музикування: профресійне та аматорське виконавство;

- існуючі музичні стилі і жанри;

- музичні твори які знаходяться в актуальному використанні, існують в аудіо, відео фрорматах, зафіксовані в нотних виданнях, рукописах; 
- а також, авторів музичного продукту (композиторів), його «реалізаторів» - виконавців, споживачів (слухачів) і всю сукупність інститутів і організацій, що сприяють зберіганню та розповсюдженню музичного продукту, зокрема, систему музичних навчальних закладів, концертних установ, музичну критику, пресу, виробників музичних інструментів, нотні видавництва тощо.

Хоча, музичне середовище в певній мірі можна розглядати як існуючу об'єктивну реальність, воно не формується само по собі. Як оточення кожного окремого суб'єкта, воно є детермінованим від нього, оскільки саме людина виступає «споживачем» і одночасно «створювачем» свого середовища. Не зважаючи на те, що вплив музичного середовища є суцільним на людей одного історичного часу, регіону, міста і т.ін., суб'єкт, водночас, може обирати «своє середовище», надаючи перевагу в уподобаннях академічному мистецтву, джазовій музиці або, наприклад, репу.

Для музиканта оточуюче середовище є одним з визначальних факторів діяльності: сприятливі умови надають можливості творчого пошуку і художньої реалізації, «удари ж середовища» (Метс Елвессон $[22,180])$ нерідко змінюють траєкторію долі митця, змушуючи трансформувати замисли, «писати в стіл» або мігрувати у пошуках кращого «музичного клімату».

Розмірковуючи про неоднорідність, нестабільність музичного середовища, здатність його до різноманітних трансформацій і змін, слід зупинитися на часо-просторовому чиннику як основному факторі, що обумовлює ці перетворення. Беззаперечним $\epsilon$ те, що плинність історичного часу i пов'язані з цим соціальні процеси впливають на формування середовища. Водночас, іншим утворюючим елементом $є$ регіональна належність. Музичне середовище окремо взятих країн, областей, міст значно різниться одне від одного. В цьому аспекті, окрім традиції, яка шляхом наслідування усталених форм музикування, фольклорних виконавських особливостей протягом довгого часу зберігає неповторність «музичного обличчя» певної території, фрактором, що фрормує музичне середовище регіону $є$ концертне життя. Насиченість гастрольними заходами, проведення різного роду фестивалів і конкурсів, активна діяльність музичних, театральних, концертних установ, розвинутий менеджмент в сфрері організації дозвілля відрізняє столичні міста від провінції. Втім, маленькі міста мають свій, неповторний, музичний мікроклімат, родзинкою якого може бути талановитий виконавець, творчий колектив, визначна мистецька акція тощо.

Висновки. Підсумовуючи можна визначити, що в термінологічному апараті музичного мистецтва поняття «музичне середовище» $є$ універсальним, оскільки охоплює всі компоненти процесу творення звукового музичного простору та його сприйняття. Незважаючи на численність та різноманітність складових, які в контексті історичних трансформацій, виявляються в більшій або меншій мірі, музичне середовище становить цілісний феномен, основою якого є музична діяльність. Складна багаторівнева структура, організована за принципом взаємозв'язку, взаємозалежності та взаємообумовленості елементів, дозволяє прирахувати його до системних явищ. Специфіка роботи внутрішніх механізмів музичного середовища ґрунтується на прямих і зворотних зв'язках, що забезпечує взаємообмін інформаційних потоків всередині системи.

В аспекті функціонування музичне середовище $є$ атрибутом суспільного життя. Воно фрормується і змінюється за часо-просторовими чинниками.

Загалом, під музичним середовищем розуміється звукове оточення індивіда, що формується в процесі музичної діяльності і охоплює всі її складові: творчість, виконавство, розповсюдження та сприйняття. Воно обумовлюється часо-просторовими чинниками та динамікою соціальних змін.

\section{תimepamypa}

1. Борисович Д. В. Музыкальная среда одно из ведущих средств полноценного музыкального образования ребенка. Педпортал. URL: http://pedportal.net/doshkolnoe-obrazovanie/raznoe/muzykal-naya-sreda-odno-iz-veduschih-sredstv-polnocennogomuzykal-nogo-obrazovaniya-rebenka-671742. (дата звернення: 25.12.2018).

2. Гельвеций К. А. О человеке, его умственных возможностях и его воспитании. Москва: Гос. соц. эконом. изд.,

3. Головач И. М. Формирование музыкальной среды большого города в святи с воздействием средств массовой коммуникации (на материалах социологических опросов молодежи Ташкента 80-х годов): ареф. дисс. ... канд. искусств.: 17.00.02. Ташкент, 1990. 23 с.

4. Кавунник О. А. Музичне середовище Ніжина в контексті національних культуротворчих процесів XIX -початку XXI століть: автореф. дис. ... канд. мист.: 17.00.03. Київ, 2011. 16 с.

5. Конт О. Дух позитивной философии. Слово о положительном мышлении / пер. с франц. И. А. Шапиро. Ростов н/Д: Феникс, 2003. 256 с. №11. С. $37-42$.

6. Костина Э. П. Музыкальная среда как средство развития креативности ребенка. Дошкольное воспитание. 2006.

7. Лісовська Т. А. Вплив музичного середовища на розвиток імпровізації в дітей дошкільного віку. Науковий вісник МНУ ім. В.О.Сухомлинського. Педагогічні науки, 2014. Вип. 1.45 (106). С.83-86.

8. Мельникас Л. Экология музикальной культуры. Москва: Композитор, 2000. 328 с.

9. Назайкинский Е. В. Музыка и экология. Музыкальная академия, 1995. №1. С.8-18.

10. Платон. Государство /пер. с греч. А. Н. Егунова. Москва: AST Publishers, 2016. 410 c.

11. Поведенческая концепция Б. Скиннера. Национальная психологическая энциклопедия URL: http://vocabulary.ru/termin/povedencheskaja-koncepcija-b-skinnera.html (дата звернення 20.01.2019).

12. Рубинштейн С. Л. Основы общей психологи. Санкт-Петербург: Питер, 2002. 720 с.

13. Савицкий П. Н. Евразийство. Россия между Европой и Азией: Евразийский соблазн. Антология. Политология: хрестоматия. Сост. М. А. Василик, М. С. Вершинин. Москва: Гардарики, 2000. 843 с. 
14. Сеченов И. М. Две заключительные лекции о значении так называемых растительных актов и животной жизни. Физиология. Избр. произ. в 4-х ч. Москва: Юрайт, 2017. Ч.2. 355 с.

15. Сеченов И. М. Элементы мысли. Избранные философские и психологические произведения. Москва: Госполитиздат, 1947. $647 \mathrm{c}$

16. Спенсер Г. Основание психологии. В 4-х т. Санкт-Петербург: изд. И. И. Билибина, 1876. 1342 с.

17. Тен И. Философия искусства / общ. ред. А. М. Микиши. Москва: Республика, 1996. 351 с.

18. Тимашева М. Лицом к событию. Гия Канчели. Интервью Радио Свобода 5 июля 2001 roда. URL: http://www.svoboda.org/a/24197955.html.(дата звернення 22.12.2018).

19. Философский энциклопедический словарь / редкол.: С. С. Аверинцев, Э. А. Араб-Оглы, Л. Ф. Ильчев и др. 2-е изд. Москва: Сов. энциклопедия, 1989. 815 с.

20. Хейдметс М. Субъект, среда и границы между ними. Психология и архитектура. Тезисы конференции в Лохусалу. Таллин: ТПИ им. Э. Вильде, 1983. С.124-137.

21. Екологічна енциклопедія: у Зт. / редкол.: А. В. Толстоухов та ін. Київ: ТОВ «Центр екологічної освіти та інфрормації», 2006. Т. 1: A-E. 432 c.

22. Элвессон М. Организационная культура / пер. с англ. П. К. Власова. Харьков: Гуманитарный центр, 2005. 460 с.

23. Adler A. The individual psychology of Alfred Adler: a systematic presentation of selections from his writings. H. L. \& R. R. Ansbacher (Eds.). New York: Basic Books, 1956. 503 p.

24. Teymur N. Environmental Discourse. London: Question Press1982. 220 p.

25. Haeckel E. Generalle Morphologie der Organismen. Bd. II. Allgemeine Entwickelungsgeschichte der Organismen. Berlin: Druck Und Erlag Von Georg Reimer, 1866, 577 s.

\section{References}

1. Borisovich, D. V. (2013). Musical environment as one of the leading means of child`s full-fledged musical education. Pedportal. Retrieved from http://pedportal.net/doshkolnoe-obrazovanie/raznoe/muzykal-naya-sreda-odno-iz-veduschih-sredstvpolnocennogo-muzykal-nogo-obrazovaniya-rebenka-671742 [in Russian].

Russian].

2. Gelvetsiy, K. A. (1938). About a human, his mental capabilities and his upbringing. Moscow: Gos. sots. ekonom. izd. [in

3. Golovach, I. M. (1990). A big city musical environment formation as a result of mass media influence (based on public opinion polls of Tashkent youth of 80-ties). Extended abstract of candidate's thesis. Tashkent: Institut iskusstvoznaniya im. Hamzyi Hakim-Zade Niyazi [in Russian].

4. Kavunnyk, O. A. (2011). Musical environment of Nizhyn within national culture forming processes of XIX - beginning of the XXI centuries. Extended abstract of candidate's thesis. Kyiv: IMFE im. M. T. Ryljsjkogho NANU [in Ukrainian].

5. Kont, O. (2003). The spirit of positive philosophy. A word on positive thinking. (I. A. Shapiro, Trans). Rostov n/D: Feniks [in Russian].

6. Kostina, E. P. (2006). Musical environment as means of child`s creativity development. Doshkolnoe vospitanie, №11, 37-42 [in Russian].

7. Lisovsjka, T. A. (2014). Preschool children`s improvisation development under the influence of musical environment. Naukovyj visnyk MNU im. V.O.Sukhomlynsjkogho. Pedaghoghichni nauky. (Vols. 1.45 (106), (pp. 83-86). Mykolajiv: MNU im. V. O. Sukhomlynsjkogho [in Ukrainian].

8. Melnikas, L. (2000). Ecology of musical culture. Moscow: Kompozitor [in Russian].

9. Nazaykinskiy, E. V. (1995). Music and ecology. Muzyikalnaya akademiya, №1, 8-18 [in Russian].

10. Platon (2016). State. (A. N. Egunova, Trans). Moscow: AST Publishers [in Russian].

11. B. Skinner's behavioral concept. (No date). Natsionalnaya psihologicheskaya entsiklopediya. Retrieved from http://vocabulary.ru/termin/povedencheskaja-koncepcija-b-skinnera.html [in Russian].

12. Rubinshteyn, S. L. (2002). Fundamentals of general psychology. St. Petersburg: Piter [in Russian].

13. Savitskiy, P. N. (2000). Eurasianism. Russia between Europe and Asia: Eurasian temptation. Anthology. Politologiya: hrestomatiya. (M. A. Vasilik, M. S. Vershinin, Comp). Moscow: Gardariki [in Russian].

14. Sechenov, I. M. (2017). Two concluding lectures about importance of so-called vegetation acts and animal life. Fiziologiya. Izbr. proiz. Moscow: YUrayt, ch. 2 [in Russian].

15. Sechenov, I. M. (1947). Elements of a thought. Izbrannyie filosofskie i psihologicheskie proizvedeniya. Moscow: Gospolitizdat [in Russian].

16. Spenser, G. (1876). Fundamentals of psychology. St. Petersburg: izd. I. I. Bilibina [in Russian].

17. Ten, I. (1996). Philosophy of art. A. M. Mikishi (Eds.). Moscow: Respublika [in Russian].

18. Timasheva, M. (2001). Facing the event. Giya Kancheli. Intervyu Radio Svoboda. Retrieved from http://www.svoboda.org/a/24197955.html [in Russian].

19. Philosophic encyclopedia. (1989). S. S. Averintsev, E. A. Arab-Oglyi, L. F. llchev et al. (Eds.). Moscow: Sov. entsiklopediya [in Russian].

20. Heydmets, M. (1983). Subject, environment and boundaries between them. Psihologiya i arhitektura. Proceedings from conference in Lohusalu. (pp. 124-137). Tallin: TPI im. E. Vilde [in Russian].

21. Ecological encyclopedia (2006). A. V. Tolstoukhov et al. (Eds.). (Vols. 1). Kyiv: TOV «Centr ekologhichnoji osvity ta informaciji» [in Ukrainian].

22. Elvesson, M. (2005). Organizational culture. (P. K. Vlasov, Trans). Kharkov: Gumanitarnyiy tsentr [in Russian].

23. Adler A. (1956). The individual psychology of Alfred Adler: a systematic presentation of selections from his writings. H. L. \& R. R. Ansbacher (Eds.). New York: Basic Books [in English].

24. Teymur N. (1982). Environmental Discourse. London: Question Press [in English].

25. Haeckel E. (1866). Generalle Morphologie der Organismen. Allgemeine Entwickelungsgeschichte der Organismen. Bd. II. Berlin: Druck Und Erlag Von Georg Reimer [in German]. 